\title{
Reduction of Liver Iron Load in Adult Patients with $\beta$-Thalassemia Major Treated with Modern Chelation Modalities
}

\author{
Pencho G. Georgiev ${ }^{1,2}$, Katja G. Sapunarova ${ }^{1,2}$, Veselina S. Goranova-Marinova ${ }^{1,2}$, Stefan E. Goranov ${ }^{1}$ \\ ${ }^{1}$ Hematology Section, First Department of Internal Medicine, Medical University of Plovdiv, Plovdiv, Bulgaria \\ ${ }^{2}$ Clinical Hematology Clinic, St George University Hospital, Medical University of Plovdiv, Plovdiv, Bulgaria
}

Corresponding author: Pencho G. Georgiev, Hematology Section, First Department of Internal Medicine, Medical University of Plovdiv, 15A Vassil Aprilov Blvd., 4002 Plovdiv, Bulgaria; E-mail: penchogeorgiev@yahoo.com; Tel.: 0888520139

Received: 28 Aug $2019 \diamond$ Accepted: 6 Dec $2019 \diamond$ Published: 30 June 2020

Citation: Georgiev PG, Sapunarova KG, Goranova-Marinova VS, Goranov SE. Reduction of liver iron load in adult patients with $\beta$-thalassemia major treated with modern chelation modalities. Folia Med (Plovdiv) 2020;62(2):265-70. doi: 10.3897/folmed.62.e39518.

\begin{abstract}
Background: Management of beta-thalassemia major (TM) requires life-long hemotransfusions leading to iron overload. Iron elimination is enhanced by the use of modern chelators.

Aim: To assess the effect of modern chelation therapy by dynamics of serum ferritin concentration and liver MRI T2*.

Patients and methods: Forty-six patients with TM (male to female ratio $=1: 1$, mean age $33.2 \pm 10.9$ years) were prospectively studied between 2011 and 2014. Twenty-one patients (45.7\%) were treated with deferasirox, 17 (37\%) - with deferiprone, and 8 (17.3\%) - with deferiprone in combination with deferoxamine. Ferritin was measured by ELISA. MRI T2* was assessed by Siemens Magnetom Avanto 1.5T. The patients were allocated into 3 groups based on their initial ferritin level and liver MRI T2*. Statistical analysis was performed using SPSS v. 18 for Windows. Data were analysed by descriptive analysis, analysis of variance and correlative analysis, means were compared using t-test and one-way ANOVA.
\end{abstract}

Results: In 2011, 9 (19.5\%) patients had normal liver MRI T2*; in 2014 they were 17 (37\%). The patients with mild grade liver siderosis were $12(26 \%)$ in 2011, and in 2014 they were 14 (30.4\%). In 2011, the patients with moderate liver siderosis were 14 (30.4\%), and in $2014-12$ (26.0\%). Eleven patients (23.9\%) had severe liver siderosis in 2011 and only two patients (4.0\%) were diagnosed with the condition in 2014.

Conclusion: A reduction of iron overload was found in all studied groups. This positive effect is attributed to the use of modern chelators and the ease of access to accurate monitoring.

\section{Keywords}

beta-thalassemia major, hepatic iron overload, ferritin, MRI T2*

\section{INTRODUCTION}

Beta-thalassemia major (TM) is a hereditary hemolytic anemia in which regular blood transfusions are the mainstay of care. However, it causes iron-overload (IO) that requires monitoring and management by long-term iron chelation therapy to prevent cell death and organic dysfunctions which can be fatal. ${ }^{1}$ The annual quantity of IO amounts to 7-14 g. ${ }^{2}$ Initially, iron accumulates in the reticuloendothelial system of bone marrow, spleen and liver, 
followed by accumulation in hepatocytes, cardiomyocytes and parenchymal cells of endocrine glands. ${ }^{3}$ The concentration of iron ions in the organism leads to organ damage by different mechanisms, thus it is a negative prognostic and survival limiting factor in patients with TM. ${ }^{4}$ Iron metabolism in the affected cells is extremely decreased. To enhance it, clinicians rely on iron-chelating agents. ${ }^{5}$ Although adequate oral iron chelation therapy is promising for the treatment of transfusional iron-overload, some patients are less compliant with it, and others suffer from long-term effects of iron overload. Different indicators capable of assessing the total IO in the body are used to monitor the effect of iron chelating agents. Ferritin is the major binding protein in the body's iron stores. It is found predominantly in the liver, spleen, and in small amounts in the serum. ${ }^{6,7}$ The availability of serum ferritin is a reason for its routine use in total IO assessment by most treatment centers. The method lacks specificity in cases of elevation of serum ferritin concentration because of inflammation, vitamin C intake or after allogeneic hematopoietic stem-cell transplantation. ${ }^{8,9}$ In such cases liver iron concentration, measured by MRI ${ }^{\star} \mathrm{T} 2$ is particularly useful. ${ }^{10}$ Most of the studies have found a very good correlation between serum ferritin concentrations and liver iron load measured by MRI ${ }^{\star} \mathrm{T} 2$ and recommended both of the methods for routine IO monitoring. ${ }^{10,11}$ Liver is the major iron storage in the body, containing approximately $70 \%$ of the total body iron. It is known that the liver iron concentration correlates with the total body IO in patients with transfusion-dependent anemia. ${ }^{12}$ This the reason why liver iron load assessment is of extreme importance for TM patients. Traditionally, the assessment of liver iron was performed by liver biopsy - an invasive method that is not tolerated well by all patients. ${ }^{13}$ Nowadays liver IO is tested by MRI T2*. The method measures iron in milligrams per gram of dry liver tissue and estimates the risk of organ damage. Liver iron concentrations higher than $1.6 \mathrm{mg} / \mathrm{g}$ of dry tissue are considered high. Values of less than $7 \mathrm{mg} / \mathrm{g}$ are associated with low risk for complications and those between 7 and $15 \mathrm{mg} / \mathrm{g}$ - with intermediate risk. Patients with $15 \mathrm{mg} / \mathrm{g}$ are proven to have serious risk of liver damage - such as fibrosis and cirrhosis. Current advances of modern chelation therapy have led to better compliance of patients with TM, less complications and higher overall and event - free survival due to more adequate elimination of IO. ${ }^{14}$

The aim of this study was to analyze the dynamics of liver IO assessed by serum ferritin concentration and MRI T2* in TM patients treated by deferasirox (DFX), deferiprone (DFP) or deferiprone (DFP) + deferoxamine (DFA) combination therapy.

\section{PATIENTS AND METHODS}

Our analysis comprised 46 TM patients followed-up in the Hematology Department of St George University Hospital in Plovdiv, Bulgaria between 2011 and 2014. All patients were on regular transfusion therapy started early in their childhood. DFX, DFP, DFP+DFA were used as chelation therapy in the three study groups. The values of serum ferritin, and MIR T2* were used for assessment of IO. According to ferritin levels the patients were allocated into the following groups: ferritin $<1000 \mu \mathrm{g} / \mathrm{ml}$, ferritin between 1000 and $2500 \mu \mathrm{g} / \mathrm{ml}$, and ferritin $>2500 \mu \mathrm{g} / \mathrm{ml}$. According to the MIR T2* values patients were allocated as follows: patients with normal liver iron load $>6.3 \mathrm{~ms}$ (corresponding to $<2$ $\mathrm{mg} / \mathrm{g}$ of dry weight); mild liver IO 2.7-6.3 ms (corresponding to $2-5 \mathrm{mg} / \mathrm{g}$ of dry weight); moderate liver IO $1.4-2.7 \mathrm{~ms}$ (corresponding to $5-10 \mathrm{mg} / \mathrm{g}$ of dry weight); severe liver IO $<1.4 \mathrm{~ms}$ (corresponding to $>10 \mathrm{mg} / \mathrm{g}$ of dry weight). Ferritin was measured using ELISA. MRI T2* was assessed by Siemens Magnetom Avanto 1.5T. Statistics were performed by descriptive statistics, analysis of variance, and correlative analysis, means were compared using one-sample t-test and one-way ANOVA (SPSS v. 18 for Windows).

\section{RESULTS}

Demographic distribution within the cohort was 23 males and 23 females (1:1) (mean age 33.2 \pm 10.9 years). Respective of treatment modality three groups were formed: group 1 consisted of 8 patients (17.3\%) (mean age $28.63 \pm 12.85$ years, males to females ratio 5:3) who received DFA + DFP, group 2 were on DFX - 21 patients (45.7\%) (mean age $32.14 \pm 10.32$ years, males to females ratio 8:13), and group 3 were on DFP - 17 patients (37\%) (mean age $31.82 \pm 10.25$ years, males to females ratio 10:7. No significant difference was found in the age and sex distribution between the groups (Fig. 1).

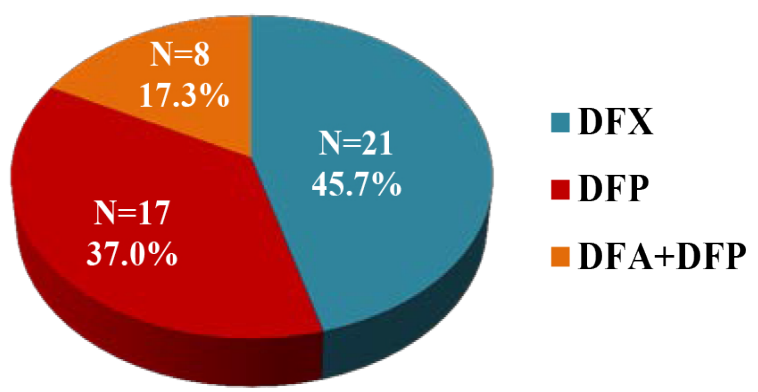

Figure 1. Distribution of patients by modality of treatment.

Over a four-year period (2011-2014), the patients receiving modern chelating agents showed a significant reduction in their IO measured by serum ferritin concentrations. The proportion of patients with ferritin $<1000 \mu \mathrm{g} /$ $\mathrm{ml}$ increased from $43.5 \%$ (20 patients) in 2011 to $65.2 \%$ (30 patients) in 2014 ( $p=0.029$ ) while the proportion of patients with ferritin $>2500 \mu \mathrm{g} / \mathrm{ml}$ decreased from $23.9 \%$ (11) to $6.2 \%$ (3) ( $p=0.033)$. The distribution in groups according to ferritin level in two time points in 2011 and 2014 is shown in Figs 2A, 2B. Improvement in IO after chelating was also 
2011

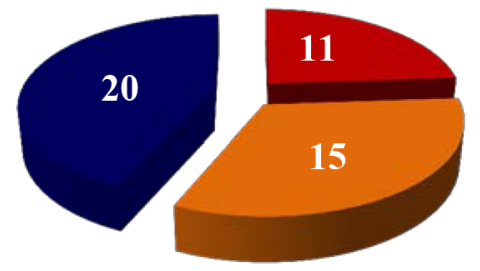

- $>2500 \mathrm{ng} / \mathrm{ml} \quad \square 1000-2500 \mathrm{ng} / \mathrm{ml} \quad \square<1000 \mathrm{ng} / \mathrm{ml}$ $2 A$

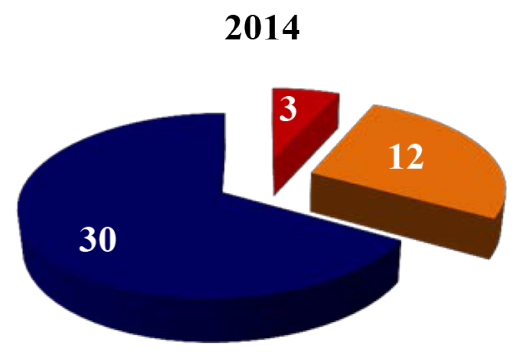

- $>2500 \mathrm{ng} / \mathrm{ml} \quad 1000-2500 \mathrm{ng} / \mathrm{ml} \quad-<1000 \mathrm{ng} / \mathrm{ml}$ 2B

Figure 2. Distribution of patients by ferritin level in 2011 (A) and in 2014 (B).

registered when measuring liver iron concentration by MRI $\mathrm{T} 2^{\star}$. In 2011, 9 (10.2\%) patients had normal levels of liver iron concentration, while in 2014 their number went up to $17(37.0 \%)(p=0.045)$. The number of patients with mild grade of liver IO in 2011 and 2014 was 12 (26.0\%) and 14 (30.4\%), respectively (NS). In 2011, the patients with moderate liver IO were $14(30.4 \%)$, in $2014-12(26.0 \%)$, NS. The group with severe IO in 2011 numbered 11 (23.9\%) patients, while after treatment their number decreased to 2 (4.3\%) patients in 2014 ( $p=0.041)$ (Figs 2A, 2B, 3).

Comparing the dynamics of serum ferritin levels at baseline and in 2014, a significant reduction was found in all three therapeutic regimens. Most expressed improvement was registered for the patients treated with DFP. (Table 1)

The beneficial dynamics in ferritin serum levels after iron-chelation therapy corresponds to the data of liver IO from MRI T2*. In all three therapeutic modalities there is a significant increase of MRI T2 $2^{\star}$ in 2014 compared to $2011(p=0.045)$. This improvement is the greatest in the
DFP-treated patients but the difference between the three treatment modalities failed to reach statistical significance (Fig. 3).

\section{DISCUSSION}

The presented data are the first single center results reported from Bulgaria. Our analysis comprises a relatively young patient's cohort (mean age $33.2 \pm 10.9$ years) that was regularly chelated since their childhood years with the only available agent at that time - DFA. The allocation to treatment modalities was implemented according to the baseline results of ferritin serum levels and MRI T2* of liver and myocardium. By the time of the initiation of modern chelation therapy ${ }^{15}$ that corresponds to the first period of our study (2011). 56.6\% of the patients had ferritin level above $1000 \mu \mathrm{g} / \mathrm{ml}, 54 \%$ had moderate to severe liver siderosis assessed by MRI T2*. In a period of 4 years (up to 2014)

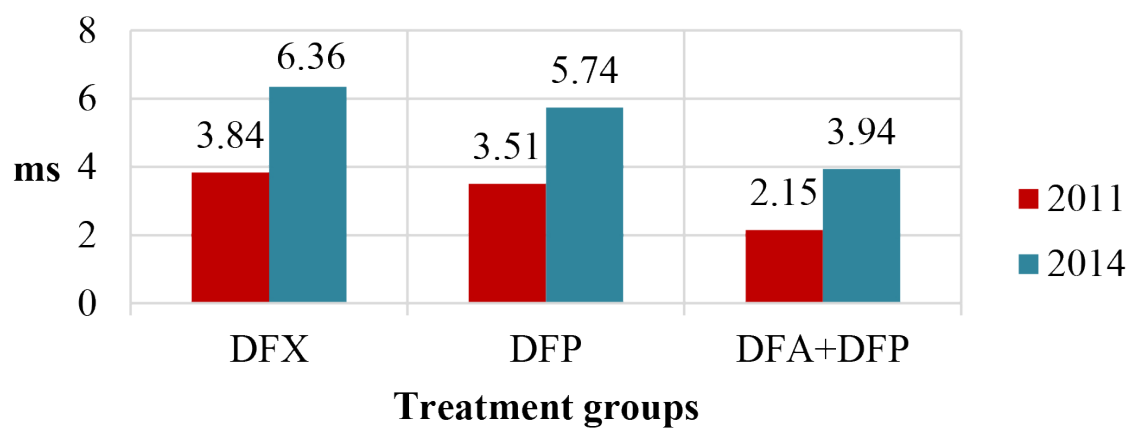

Figure 3. MRI T2* Dynamics according to the treatment modality.

Table 1. Dynamics of serum ferritin reduction according to the treatment modality

\begin{tabular}{cccc}
\hline $\begin{array}{c}\text { Treatment } \\
\text { Modality }\end{array}$ & $\begin{array}{c}\text { Ferritin in 2011 } \\
(\text { mean } \pm \text { SEM) } \boldsymbol{\mu g} / \mathbf{m l}\end{array}$ & $\begin{array}{c}\text { Ferritin in 2014 } \\
(\text { mean } \pm \text { SEM) } \boldsymbol{\mu g} / \mathbf{m l}\end{array}$ & $p$ value \\
\hline DFX & $1606 \pm$ & $1284 \pm$ & 0.033 \\
DFP & $1374.9 \pm$ & $744.64 \pm$ & 0.019 \\
DFP+DFA & $1986 \pm$ & $1642 \pm$ & 0.035 \\
\hline
\end{tabular}


the proportion of patients with ferritin level above $1000 \mu \mathrm{g} /$ $\mathrm{ml}$ decreased to $33.3 \%$ and the proportion of patients with moderate and severe liver siderosis - to $31 \%$. These results are relevant to the most of the published data. Many authors consider the significant liver IO level reduction as a result of the more convenient oral forms of chelators and better adherence to therapy. ${ }^{16,17}$ Considering the therapeutic allocation, it should be noted that the group treated with DFP benefits the most in terms of ferritin level reduction. Comparable reduction in ferritin level is reported in the cohorts treated by DFX and DFA+DFP. Simultaneously, the average increase in MRI T2* in patients on DFX and DFP are similar, while in the group on combined therapy with DFP+DFA the observed increase remains unsatisfactory. Results similar to ours have been reported by Angulo I et al. (2008). ${ }^{2}$ According to Karakas $\mathrm{Z}$ et al. patients with follow-up MRI examinations exhibited significant improvement in liver iron concentration, measured as increase in hepatic $\mathrm{T} 2^{*}$ values. The decrease of liver iron concentration was prominent in the DFX group $(p<0.01)$. The authors also report that serum ferritin level was significantly correlated with liver iron concentrations ( $\mathrm{rs}=0.65, p<0.001)$, hepatic T2* value ( $\mathrm{rs}=-0.62, \mathrm{p}<0.001)$, but not with cardiac T2* value ( $r s=-0.20, p=0.07$ ) (18). In a one-year follow-up Vitrano A et al. found that LIC significantly decreased from MRI1 to MRI2 and $7.7 \%$ of patients shifted from LIC values of high risk to an intermediate-risk category after chelator therapy. Median change in LIC and correlation with serum ferritin levels has been reported. ${ }^{19}$ Confirmation of these important findings for a 4 -year period is provided by our study in a similar population of patients. Mean T2* MRI value or mean changes in $\mathrm{T} 2^{\star} \mathrm{MRI}$ value after usage of iron chelators is widely reported. ${ }^{20-24}$ There is evidence that prove better control and increase of myocardial T2* MRI in those with DFP, and of liver $\mathrm{T}^{*}$ in those with good adherence to DFA chelation. ${ }^{25}$ Our results do not show significant advantage of one over another treatment modality, although there is a tendency for better results in the DFP group. Larger patient cohorts and longer period of observation are needed to confirm this finding. In our analysis, the most unsatisfactory results from IO control were registered in the combined therapy group. This could be explained by the fact that the patients allocated to it were a priori showing much higher level of IO. Similar are the findings of Eghbali A et al. in a one-year follow-up. ${ }^{26}$ Moreover, the subcutaneous application of DFA is a factor contributing to lower compliance to therapy. Combination chelation may be effective but adverse effects and adherence challenges limit its efficacy.

\section{CONCLUSIONS}

Patients with TM on iron-chelation therapy show stable and significant improvement of IO assessed by serum ferritin level and liver MRI T2*. This can be accounted for by the introduction of modern oral chelators in clinical practice, their convenient oral intake, resulting in better adherence. The ease of access to accurate follow-up methods allows personalized treatment and better outcome. Oral iron chelation agents are associated with a significant reduction of iron toxicity-induced morbidity and mortality, improvement in quality of life, overall and event-free survival in transfusion-dependent patients with $\beta$-thalassemia major. ${ }^{27}$

\section{Conflict of Interest}

The authors declare no conflict of interest.

\section{REFERENCES}

1. Argyropoulou MI, Astrakas L. MRI evaluation of tissue iron burden in patients with $\beta$-thalassaemia major. Pediatr Radiol 2007; 37: 1191.

2. Angulo I, Covas D, Carneiro N, et al. Determination of iron-overload in thalassemia by hepatic MRI and ferritin. Revista Brasileira de Hematologia e Hemoterapia 2008; 30(6): 449-52.

3. Rund D, Rachmilewitz EA. Medical progress - $\beta$-thalassemia. Review article. N Engl J Med 2005; 353: 1135-46.

4. Old JM, Olivieri NF, Thein SL. Diagnosis and management of thalassemia. In: Weatherall DJ, Clegg B, eds. The thalassaemia syndromes. 4th ed. Oxford, England: Blackwell Science; 2001, 630-85.

5. Hershko CA, Link GK, Cabantchik ZI. Objectives and mechanism of iron chelation therapy. Annals of the New York Academy of Sciences. 2005; 1054: 124-35.

6. Torti FM, Torti SV. Regulation of ferritin genes and protein. Blood 2016; 99(10): 3505-16.

7. Karnolski A. Red blood cell disorders. In: Clinical Hematology, part I, Medicina I Fizkultura, Sofia: 2003; 86-90.

8. Porter JB, Elalfy M, Taher A, et al. Limitations of serum ferritin to predict liver iron concentration responses to deferasirox therapy in patients with transfusion-dependent thalassaemia. Eur J Haematol 2017; 98(3): 280-8.

9. Jarisch A, Salzmann-Manrique E, Cario H, et al. Serum ferritin is not a reliable predictor to determine iron overload in thalassemia major patients post-hematopoietic stem cell transplantation. Eur J Haematol 2018; 101(6): 791-7.

10. Bonkovsky HL, Rubin RB, Cable EE, et al. Hepatic iron concentration: noninvasive estimation by means of MR imaging technique. Radiology 1999; 212: 227-34.

11. Kanbour I, Chandra P, Soliman A, et al. Severe liver iron concentrations (LIC) in 24 patients with $\beta$-thalassemia major: correlations with serum ferritin, liver enzymes and endocrine complications. Mediterr J Hematol Infect Dis 2018; 10(1): e2018062.

12. Angelucci E, Brittenham GM, McLaren CE, et al. Hepatic iron concentration and total body iron stores in thalassemia major. N Engl J Med 2000; 343(5): 327-31.

13. Angelucci E, Baronciani D, Lucarelli G, et al. Needle liver biopsy in thalassaemia: analyses of diagnostic accuracy and safety in 1184 consecutive biopsies. British Journal of Haematology 1995; 89: $757-61$. 
14. Taher A, Nathan D, Porter JD. Evaluation of iron levels to avoid the clinical sequelae of iron overload. Semin Hematol 2007; 44 (Suppl 3): S2-S6.

15. Dimitrova K. Stoyanova D. [Iron chelating therapy in patients with beta-thalassaemia.] MD 2009; 6: 12-7 [Article in Bulgarian].

16. Kaleva V, Mihaylov G, Peychev D, et al. [Methodological guidance on diagnosing, treatment and follow-up of patients with disorders of blood and hematopoietic system]. Bulgarian Scientific Society of Clinical Hematology and Transfusion Medicine, Ver 2, May 2011 [Article in Bulgarian].

17. Taher A, Elalfy MS, Al Zir K, et al. Achieving treatment goals of reducing or maintaining body iron burden with deferasirox in patients with $\beta$-thalassaemia: results from the ESCALATOR study. Eur J Haematol 2011; 87(4): 349-54.

18. Karakas Z, Yilmaz Y, Bayramoglu Z, et al. Magnetic resonance imaging during management of patients with transfusion-dependent thalassemia: a single-center experience. Radiol Med 2018; 123(8): 572-6.

19. Vitrano A, Sacco M, Rosso R, et al. Longitudinal changes in LIC and other parameters in patients receiving different chelation regimens: Data from LICNET. Eur J Haematol 2018; 100(2): 124-30.

20. Cappellini M, Bejaoui M, Agaoglu L, et al. Iron chelation with deferasirox in adult and pediatric patients with thalassemia major: efficacy and safety during 5 years' follow-up. Blood 2011; 118(4): 884-93.
21. Rachmilewitz EA, Giardina PJ. How do I treat thalassemia. Blood 2011; 118: 3479-88.

22. Adamkiewicz T, Abboud M, Paley C, et al. Serum ferritin level changes in children with sickle cell disease on chronic blood transfusion are nonlinear and are associated with iron load and liver injury. Blood 2009; 114(21): 4632-8.

23. Barry M, Flynn DM, Letsky EA, et al. Long-term chelation therapy in thalassemia major: effect on liver iron concentration, liver histology, and clinical progress. BMJ 1974; 2: 16-20.

24. Totadri S, Bansal D, Trehan A, et al. Hepatic and cardiac iron-load in children on long-term chelation with deferiprone for thalassemia major. Indian Pediatr 2018; 55(7): 573-5.

25. Wahidiyat PA, Yosia M, Sari TT. Comparison of deferiprone to deferasirox and deferoxamine to cardiac and hepatic T2* MRI in thalassemia patients: evidence-based case report. Acta Med Indones 2018; 50(2): 168-76.

26. Eghbali A, Shokri P, Afzal RR, et al. A 1-year randomized trial of deferasirox alone versus deferasirox and deferoxamine combination for the treatment of iron overload in thalassemia major. Transfus Apher Sci 2019; 2019; 58(4): 429-33.

27. Ballas SK, Zeidan AM, Duong VH, et al. The effect of iron chelation therapy on overall survival in sickle cell disease and $\beta$-thalassemia: A systematic review. Am J Hematol. 2018; 93(7): 943-52. 


\section{Снижение накопления избытков железа в печени у пожилых пациентов с большой $\beta$-талассемией при помощи современных методов хелатирования}

Пенчо Г. Георгиев ${ }^{1,2}$, Катя Г. Сапунарова ${ }^{1,2}$, Веселина С. Горанова-Маринова ${ }^{1,2}$, Стефан Е. Горанов $^{1}$

${ }^{1}$ Секция гематологии, Первая кафедра внутренних болезней, Медицинский университет-Пловдив, Пловдив, Болгария

${ }^{2}$ Клиника клинической гематологии, УМБАЛ „Св. Георги “, Медицинский университет-Пловдив, Пловдив, Болгария

Адрес для корреспонденции: Пенчо Г. Георгиев, Секция гематологии, Первая кафедра внутренних болезней, Медицинский университет-Пловдив, бул. „Васил Априлов“ № 15А 4002 Пловдив, Болгария; E-mail: penchogeorgiev@yahoo.com; Tel.: 0888520139

Дата получения: 28 августа 2019 Дата приемки: 6 декабря 2019 Дата публикации: 30 июня 2020

Образец цитирования: Georgiev PG, Sapunarova KG, Goranova-Marinova VS, Goranov SE. Reduction of liver iron load in adult patients with $\beta$-thalassemia major treated with modern chelation modalities. Folia Med (Plovdiv) 2020;62(2):265-70. doi: 10.3897/ folmed.62.e39518.

\section{Абстракт}

Введение: Контроль большой $\beta$-талассемии (БТ) требует переливания крови в течение всей жизни, что приводит к накоплению избытков железа. Удаление железа улучшается за счёт использования современных хелаторов.

Цель: Оценить влияние современной хелатной терапии посредством динамики сывороточной концентрации ферритина и МТР Т2* печени.

Пациенты и методы: Сорок пять пациентов с БТ (соотношение мужчин и женщин 1: 1, средний возраст 33,2 $\pm 10,9$ года) были обследованы в проспективном исследовании в период с 2011 по 2014 год. Двадцать один пациент (45,7\%) проходил лечение деферазироксом, 17 (37\%) - деферипроном и 8 (17,3\%) - деферипроном в сочетании с дефероксамином. Ферритин был измерен с помощью ELISA. MPT T2 * выполняли с помощью Siemens Magnetom Avanto 1.5T. Пациенты были разделены на три группы в зависимости от исходного уровня ферритина и МРТ Т2 ${ }^{*}$ печени. Статистический анализ проводился с использованием SPSS v. 18 для Windows. Данные были проанализированы с помощью описательного анализа, анализа дисперсии и анализа соотношения, значения были сопоставлены с использованием Т-теста и one-way ANOVA.

Результаты: В 2011 году у 9 (19,5\%) пациентов была нормальная МРТ Т2 ^печени; в 2014 году их было 17 (37\%). Пациентов с лёгким сидерозом печени было 12 (26\%) в 2011 году и 14 (30,4\%) в 2014 году. В 2011 году количество пациентов с умеренным сидерозом печени составило 14 (30,4\%), а в 2014 году - 12 (26,0\%). Одиннадцать пациентов (23,9\%) имели тяжёлый сидероз печени в 2011 году, и только у двух пациентов (4,0\%) было диагностировано заболевание в 2014 году.

Заключение: Снижение накопления избытков железа было установлено во всех изученных группах. Положительный эффект объясняется использованием современных хелаторов и облегчённым доступом к точному мониторингу.

\section{Ключевые слова}

